\title{
TYYPILLISESTI KEHITTYNEIDEN LASTEN JA LASTEN, JOILLA ON KIELELLINEN ERITYISVAIKEUS TAI AUTISMIKIRJON HÄIRIÖ, SUORIUTUMINEN EDMONTON NARRATIVE NORMS INSTRUMENT (ENNI) -KERRONTATESTISSÄ
}

\author{
Leena Mäkinen, Oulun yliopisto, Logopedian \\ tutkimusyksikkö, Lapsenkielen tutkimuskeskus \\ Soile Loukusa, Oulun yliopisto, Logopedian \\ tutkimusyksikkö, Lapsenkielen tutkimuskeskus \\ Sari Kunnari, Oulun yliopisto, Logopedian \\ tutkimusyksikkö, Lapsenkielen tutkimuskeskus
}

\begin{abstract}
Tässä tutkimuksessa tarkasteltiin 4-8-vuotiaiden ( $N=171)$ tyypillisesti kehittyneiden lasten suoriutumista Edmonton Narrative Norms Instrument (ENNI) -kerrontatestissä. Lisäksi tutkittiin testin kykyä erotella lapset, joilla on kielellinen erityisvaikeus ( $N=19)$ tai autismikirjon häiriö $(N=16)$ ikään ja sukupuoleen kaltaistetuista verrokkilapsista. Kertomuksista analysoitiin tarinan sisällön määrä kertomuskielioppikategorioiden mukaisesti arvioituna ja tuotettujen sanojen kokonaismäärä. Tulosten perusteella voidaan todeta, että sisällön ilmentäminen ja tuotettujen sanojen kokonaismäärä kehittyivät iän myötä. Erityisesti ENNI-testi näyttäisi erottelevan 4-5- ja 5-6-vuotiaat tyypillisesti kehittyneet lapset toisistaan ja vanhemmista ikäryhmistä. Sukupuolten välisiä eroja kerrontataidoissa ei havaittu. Ne lapset, joilla on kielellinen erityisvaikeus tai autismikirjon häiriö, suoriutuivat verrokkilapsiaan heikommin tarinan sisällön ilmentämisessä. Kielihäiriöisten lasten kertomukset olivat lisäksi verrokkilasten tarinoita lyhempiä. Koska suomalaislasten kerrontataitojen arvioimiseen on käytettävissä varsin niukasti tutkittuja menetelmiä, ENNI-testi voi tuoda tarvittavan lisän paikkaamaan tätä puutetta. Viitearvojen käytössä tulee kuitenkin olla varovainen, koska suuri vaihtelu on kerronnalle tyypillistä.
\end{abstract}

Avainsanat: autismikirjo, kerronta, kielellinen erityisvaikeus, tarinan luominen, tyypillinen kielenkehitys

Kirjoittajan yhteystiedot:

Leena Mäkinen

Oulun yliopisto, Logopedian tutkimusyksikkö, Lapsen-

kielen tutkimuskeskus

PL 1000, 90014 Oulun yliopisto

leena.makinen@oulu.fi

\section{JOHDANTO}

Kertomuksella eli narratiivilla tarkoitetaan tosielämän tapahtumiin tai mielikuvitukseen perustuvan tapahtumasarjan kielellistä kuvausta. Kerronta on taito, joka edellyttää laajaalaisesti monenlaisen kielellisen tiedon omaksumista (esim. Mäkinen, 2014). Kertomuksen 
tulisi olla kuulijalle ymmärrettävä siten, että se sisältää tarvittavan informaation ja että siinä käytetyt ilmaisut linkittyvät toisiinsa koherentisti muodostaen eheän kokonaisuuden. Näin ollen kertojan on huomioitava kommunikaatiotilanteen tilannetekijät (pragmaattinen ymmärtäminen), mutta myös hallittava kielen taivutusjärjestelmään, lauserakenteisiin ja sanastoon liittyviä taitoja (lingvistiset piirteet) (Leinonen, Letts \& Rae Smith, 2000).

Logopedisessa tutkimuksessa kerrontaa arvioidaan tyypillisesti käyttäen tarinan uudelleen kerrontaa tai tarinan luomista, jotka eroavat toisistaan merkittävästi. Uudelleen kerronnassa lapselle annetaan tarinan malli, mutta tarinan luominen on tehtävä, jossa lapsi itse muodostaa tarinan mentaalisen mallin, joskin useimmiten kuvasarjan auttamana. Tutkimuksissa on huomattu, että uudelleen kerronta stimuloi tuottamaan lauserakenteiltaan monipuolisempia ja sisällön suhteen informatiivisempia tarinoita kuin tarinan luominen (Duinmeijer, de Jong \& Scheper, 2012; Kunnari, Välimaa \& Laukkanen-Nevala, 2016; Schneider, 1996; Schneider \& Dubé, 2005). Edellä mainittuihin tehtävien välisiin eroihin vaikuttanee asetelma, sillä uudelleen kerronnassa lapsi pystyy hyödyntämään annettua tarinan mallia. Tarinan luominen voikin antaa luotettavamman kuvan lapsen aidoista kerrontataidoista, kun valmista tarinan mallia ei ole tarjolla (ks. esim. Leinonen ym., 2000; Schneider, 1996). Tarinan uudelleen kerronta ja luominen edellyttävät myös osittain erilaisia kognitiivisia taustataitoja. Uudelleen kerronnan on todettu olevan yhteydessä työmuistiin, mutta tarinan luomisessa vastaavaa yhteyttä ei havaittu (Duinmeijer ym., 2012; Mäkinen, Loukusa \& Kunnari, 2016). Sen sijaan tarinan luomisen ja tarkkaavuuden välillä on löydetty yhteys, mitä ei vastaavasti ole havaittu uudelleen kerronnassa (Duinmeijer ym., 2012).

Kerrontaa arvioitaessa tarkastelun paino- pisteenä ovat usein ne kielelliset keinot, joilla kertomus kerrotaan ja se, mitä merkitystä tarina kantaa. Kerronnan lingvististä rakentumista voidaan analysoida esimerkiksi tarkastelemalla käytettyjä lauserakenteita, ilmaisun keskipituutta, sanaston laatua ja tuotetun puhunnoksen määrää eli produktiivisuutta (ks. esim. Bishop, 2004; Mäkinen, 2014; Schneider, Dubé \& Hayward, 2005). Fiktiivisten tarinoiden merkityssisältöä puolestaan mitataan usein käyttäen kertomuskielioppia (story grammar). Kertomuskielioppi, kuten esimerkiksi Steinin ja Glennin (1979) malli, on prototyyppinen hyvän tarinan kuvaus, jonka avulla tarinoista voidaan löytää niille tyypillinen skemaattinen rakenne. Mallin mukaan tarinat koostuvat erilaisista elementeistä eli kertomuskielioppiluokista, joita ovat esimerkiksi tarinan käynnistävä alkutapahtuma, sen aiheuttama toiminta ja toiminnan lopputulos (ks. tarkemmin esim. Stein \& Glenn, 1979; Suvanto, 2012).

Kerrontataitoja, niiden kehitystä ja kerronnassa ilmeneviä vaikeuksia on tutkittu viime vuosina runsaasti. Tutkimuskirjallisuuden perusteella tarinan sisällön ilmentäminen näyttää kehittyvän erityisesti noin kolmesta tai neljästä ikävuodesta alkaen (Khan ym., 2016; Mäkinen, Loukusa, Nieminen, Leinonen \& Kunnari, 2014; Schneider, Hayward \& Dubé, 2006) aina kouluikään asti (To, Stokes, Cheung \& T'sou, 2010). Kehitystä tapahtuu tämän jälkeenkin, sillä yhdeksänvuotiaiden tarinat eivät ole vielä aikuisten kertomusten kaltaisia (Berman \& Slobin, 1994). Myös kerronnan lingvistisessä rakenteessa tapahtuu iänmukaista kehitystä. Lasten kasvaessa kertomusten produktiivisuus lisääntyy, ja erityisesti kehitystä näyttäisi jälleen tapahtuvan ennen kouluikää (Mäkinen, Loukusa, Nieminen ym., 2014; Westerveld, Gillon \& Miller, 2004). Justice ym. (2006) havaitsivat produktiivisuuden ja lauserakenteiden monipuolisuuden kehittyvän 5 ja 10 ikävuoden vä- 
lillä, mutta tätä vanhemmilla lapsilla kehitystä ei enää näkynyt. Westerveldin ja Moranin (2013) mukaan produktiivisuus kehittyy kuitenkin aina varhaisaikuisuuteen asti.

Tyttöjen ja poikien välisiä eroja kerronnassa on tutkittu vielä melko niukasti. Sukupuolen ei kuitenkaan ole todettu vaikuttavan kerronnan sisällön määrään, kun sitä on arvioitu kertomuskieliopin avulla (Eriksson \& Rajala, 2014; Fernandez, 2013; Mavis, Tunçer \& Gagarina, 2016; Price, Roberts \& Jackson, 2006). Toisaalta Fey, Catts, Proctor-Williams, Tomblin ja Zhang (2004) havaitsivat, että tyttöjen kertomukset olivat laadukkaampia kuin poikien, sillä tyttöjen tarinat sisälsivät enemmän informaatiota ja olivat juonellisesti monimutkaisempia. Kertomusten produktiivisuuden suhteen aiempi tutkimus on osoittanut, että tytöt tuottavat poikia pidempiä tarinoita, kun kerrontaa on mitattu tuotettujen lauseiden (Fernandez, 2013), kommunikaatioyksiköiden tai eri sanojen avulla (Fey ym., 2004).

Useissa tutkimuksissa on havaittu, että kerronnan vaikeuksia esiintyy lapsilla, joilla on kielellinen erityisvaikeus (specific language impairment, SLI) (esim. Duinmeijer ym., 2012; Fey ym., 2004; Norbury, Gemmel \& Paul, 2013; Schneider ym., 2006; To et al., 2010). Mäkisen, Loukusan, Laukkasen, Leinosen ja Kunnarin (2014) tutkimuksessa huomattiin, että SLI-lasten kerronta oli laaja-alaisesti tyypillisesti kehittyviä lapsia heikompaa sekä lingvististen (produktiivisuus, lauserakenteiden monipuolisuus, kieliopillisuus) että pragmaattisten (kertomuksen sisältö, mentaalisen sanaston käyttö, viittaussuhteiden tarkkuus) piirteiden osalta. Baixaulin, Colomerin, Rosellón ja Mirandan (2016) meta-analyysissa kerronnan huomattiin olevan kokonaisvaltaisesti haastavaa myös niille lapsille ja nuorille, joilla on autismikirjon häiriö (autism spectrum disorder, ASD). Sekä lingvistiset (lauserakenteiden hallinta, kerronnan produktiivisuus) että pragmaattiset (merkityssisällön ilmentäminen, viittaussuhteiden tarkkuus, mentaalisen sanaston käyttö) kerronnan piirteet olivat autismikirjon henkilöille haastavia, mutta erityisen vaikeaksi kerronnan elementiksi osoittautui tarkkojen viittaussuhteiden käyttö ja merkityssisällön riittävä ilmentäminen. Vaikka meta-analyysi osoitti, että autismikirjon henkilöillä on laaja-alaisia kerronnan vaikeuksia, yksittäisissä tutkimuksissa on huomattu myös vastakkaisia tuloksia. Esimerkiksi kertomuksen pituuden (Mäkinen, Loukusa, Leinonen ym., 2014; Suh ym., 2014) tai kertomuksen sisällön (Norbury \& Bishop, 2003; Norbury ym., 2013; Young, Diehl, Morris, Hyman \& Bennetto, 2005) suhteen autismikirjon lapset eivät ole aina eronneet verrokeistaan.

\section{TUTKIMUKSEN TARKOITUS}

Vaikka suomalaisia lasten kerrontataitojen tutkimuksia on julkaistu viime vuosina (ks. esim. Hakala, 2013; Huttunen \& Ryder, 2012; Kunnari ym., 2016; Lepola, Peltonen \& Korpilahti, 2009; Mäkinen, 2014; Suvanto, 2012), ei kerrontataitojen arviointiin ole käytettävissä vielä lainkaan normitettuja menetelmiä. Uudelleen kerrontaan perustuvaa brittiläistä Bus Story -testiä (Renfrew, 1997) käytetään kliinisessä puheterapiatyössä, mutta testin suomalaisversioon on saatavissa ainoastaan suuntaa-antavia viitearvoja (Lahtinen, 1997). Sen sijaan tarinan luomiseen perustuvia kerrontatestejä ei ole, joskin joitain viitearvoja 6-7-vuotiaille on kartoitettu opinnäytetöissä käyttäen Mayerin (1969) Sammakkotarinana tunnettua kirjaa Frog where are you? (Eriksson \& Rajala, 2014). Lisäksi eurooppalaisessa yhteistyössä kehitettyyn MAIN-menetelmään (Gagarina ym., 2012) on julkaistu alustavia viitearvoja. Tämän tutkimuksen tarkoituksena on tarkastella Edmonton Narrative Norms Instrument (ENNI) -kerrontatestin (Schnei- 
der ym., 2005) toimivuutta suomalaisilla tyypillisesti kehittyneillä 4-8-vuotiailla lapsilla ja tutkia testin soveltuvuutta kielellisten vaikeuksien tunnistamisessa pienellä joukolla lapsia, joilla on kielellinen erityisvaikeus tai autismikirjon häiriö. Uuden kerrontatehtävän saaminen suomalaisten puheterapeuttien kliinisen työn tueksi on ensiarvoisen tärkeää ja parantaa lasten kielellisten taitojen luotettavaa arviointia ja myös mahdollisen kuntoutuksen kohdentamista kerronnan ydinongelmiin. Tutkimuskysymykset ovat:

Eroavatko 4-8-vuotiaat tyypillisesti kehittyvät lapset toisistaan ENNI-testin tarinan sisällön ja kokonaissanamäärän suhteen tarkasteltuna?

Eroavatko lapset, joilla on kielellinen erityisvaikeus tai autismikirjon häiriö, verrokkilapsistaan ENNI-testin tarinan sisällön ja kokonaissanamäärän suhteen tarkasteltuna?

\section{MENETELMÄT}

\section{Tutkittavat}

Tutkimukseen osallistui 171 tyypillisesti kielellisissä taidoissaan kehittynyttä lasta, 19 lasta, joilla on diagnosoitu kielellinen erityisvaikeus (SLI) ja 16 lasta, joilla on autismikirjon häiriö (ASD) (ks. tarkemmin alla). Tutkimus on saanut puoltavat lausunnot Pohjois-Pohjanmaan sairaanhoitopiirin alueelliselta eettiseltä toimikunnalta sekä Oulun kaupungin varhaiskasvatusjohtajalta. Tutkimukseen osallistuminen oli vapaaehtoista ja edellytti vanhempien antamaa kirjallista suostumusta. Tutkimus toteutettiin yksilöllisesti ja tutkimustilanne videoitiin myöhempää analysointia varten.

Tyypillisesti kielellisissä taidoissaan kehittyneiden lasten ryhmä koostui 4-8-vuotiaista lapsista, joiden kotikieli oli suomi. Lapset tavoitettiin tutkimukseen oululaisista päiväkodeista ja kouluista ja 7 - ja 8-vuotiaita lapsia tutkittiin myös tamperelaisessa koulussa. Tutkittavien varhaista kielenkehitystä kartoitettiin vanhempien täyttämän lomakkeen avulla. Kellään tutkimukseen osallistuvalla lapsella ei ollut esiintynyt varhaisvaiheissa mitään huolestuttavaa, kaikilla oli normaali kuulo, eikä kukaan ollut saanut säännöllistä puheterapiaa. Yksittäinen äännevirhe ei ollut este osallistumiselle. Tarkempi tutkimusaineiston kuvaus on esitetty taulukossa 1.

Taulukko 1. Tyypillisesti kehittyneiden lasten aineiston kuvaus.

\begin{tabular}{|c|c|c|c|c|c|}
\hline & 4-vuotiaat & 5-vuotiaat & 6-vuotiaat & 7-vuotiaat & 8-vuotiaat \\
\hline $\begin{array}{l}\text { Tutkittavien } \\
\text { lukumäärä }\end{array}$ & 29 & 36 & 39 & 37 & 30 \\
\hline Pojat/ tytöt & $15 / 14$ & $18 / 18$ & 22/17 & $15 / 22$ & $15 / 15$ \\
\hline \multicolumn{6}{|l|}{ Ikä (v;kk) } \\
\hline keskiarvo & $4 ; 5$ & $5 ; 5$ & $6 ; 6$ & $7 ; 8$ & $8 ; 4$ \\
\hline keskihajonta & $0 ; 3$ & $0 ; 3$ & $0 ; 3$ & $0 ; 3$ & $0 ; 3$ \\
\hline vaihteluväli & $4 ; 1-4 ; 11$ & $5 ; 0-5 ; 11$ & 6;0-6;10 & $7 ; 0-7 ; 11$ & $8 ; 0-8 ; 10$ \\
\hline
\end{tabular}




\section{Lapset, joilla on diagnosoitu kielellinen} erityisvaikeus, tavoitettiin Oulun yliopistollisen sairaalan audiofoniatrisen yksikön kautta. Lapsista 14 oli poikia ja 5 tyttöjä. Tutkittavien ikä vaihteli välillä 5;0-7;7 vuotta, iän keskiarvo oli 6;1 vuotta ja keskihajonta 0;7 vuotta. Lapsille muodostettiin verrokkiryhmä valitsemalla tyypillisesti kehittyvien lasten aineistosta ikään ja sukupuoleen kaltaistetut verrokkilapset ( $\mathrm{N}=19,14$ poikaa, 5 tyttöä). Verrokkilasten ikä vaihteli välillä 4;11-7;5 vuotta, iän keskiarvo oli 6;2 vuotta ja keskihajonta 0;9 vuotta.

\section{Lapset, joilla on diagnosoitu autismikir-} jon häiriö, tavoitettiin Oulun yliopistollisen sairaalan lastenpsykiatrian ja lasten neurologian yksiköiden avulla. Kaikki tutkimukseen osallistuneet lapset sijoittuivat kognitiivisilta taidoiltaan tavanomaisen ikävaihtelun sisälle. Lapsista 15 oli poikia ja 1 tyttö. Tutkittavien iän keskiarvo oli 7;7 vuotta, keskihajonta 1;7 vuotta ja ikä vaihteli välillä 5;1-10;7. Tyypillisesti kehittyvien lasten aineistosta valittiin ikään ja sukupuoleen kaltaistetut verrokkilapset ja lisäksi rekrytoitiin kaksi yli 8-vuotiasta lasta lisää, koska autismikirjon lasten ryhmässä oli mukana kaksi vanhempaa lasta. Verrokkilasten $(\mathrm{N}=19,15$ poikaa, 1 tyttö) ikä vaihteli välillä 5;2-10;0 vuotta, iän keskiarvo oli 7;5 vuotta ja keskihajonta 1;5 vuotta.

\section{Menetelmä}

Kerrontataitoja arvioitiin käyttämällä $E d$ monton Narrative Norms Instrument (ENNI) -testiä ${ }^{1}$ (Schneider ym., 2005). ENNI on professori Schneiderin ja hänen kollegoidensa

1 ENNI on tekijänoikeudella suojattu menetelmä, mutta käytettävissä vapaasti kliinisessä työssä ja tutkimustarkoituksissa. Kuvat ja manuaali ovat ladattavissa Albertan yliopiston verkkosivuilta (www.rehabresearch. ualberta.ca/enni), mutta julkaisutarkoituksiin tarvitaan testintekijän lupa. Tätä tutkimusta varten on saatu suostumus professori Schneiderilta, jonka kanssa on myös keskusteltu testin pisteyttämiseen liittyvistä asioista. kehittämä menetelmä 4-9-vuotiaiden lasten kerrontataitojen arvioimiseen. Testi on normitettu Edmontonissa, Kanadassa 377 lapsella. ENNI-testi muodostuu kuudesta erillisestä kuvasarjasta, joiden vaikeustaso vaihtelee, mutta vain kahteen tarinaan (A1 ja A3) on saatavilla englanninkieliset viitearvot. Tähän tutkimukseen valittiin A3-tarina, joka koostuu 13 kuvasta ja jossa esiintyy neljä henkilöä ja kolme episodia. A1-tarina on viisisivuinen ja rakenteeltaan yksinkertaisempi. Näin ollen A3 on haastavampi ja soveltunee paremmin myös jo kouluikäisille lapsille. Tarinan juoni etenee kertomuskielioppikategorioiden mukaisesti. Aluksi ystävykset kirahvi ja norsu alkavat leikkiä lentokoneella. Norsutyttö haluaa kuitenkin itse lennättää lennokkia ja sieppaa sen kirahvin kädestä, minkä seurauksena lentokone tippuu uimaaltaaseen. Lentokonetta yrittää tuloksetta pelastaa paikalle tullut uimavahti, mutta lopulta lentokoneen pelastaa haavilla naisnorsu. Kirahvi saa lelunsa takaisin ja tarina päättyy onnellisesti. ENNI-testiä käytettäessä testin kuvat tulostetaan ja sidotaan kirjan muotoon. Testaustilanteessa tutkija ja tutkittava istuvat pöydän ääressä vastakkain ja tutkija näyttää kuvat lapselle niin, että ainoastaan lapsi näkee ne. Aluksi tutkija kertoo, että lapsi saa katsoa tarinan kuvat rauhassa läpi. Tämän jälkeen on lapsen vuoro kertoa itse tarina kuvista. Tutkija korostaa, että lapsen tehtävänä on kertoa todella tarkasti, koska tutkija ei voi nähdä kuvia. Koko testin aikana tutkija kääntää kirjan sivuja lapsen kerronnan edetessä, eikä lapsi itse koske kirjaan. ENNIn esitysohjeet on kuvattu testin verkkosivuilla (Schneider ym., 2005), joihin tulisi perehtyä ennen testin suorittamista.

\section{Analyysit}

ENNIn avulla kerrontaa voidaan arvioida laaja-alaisesti. ENNIssä on englanninkieli- 
set viitearvot seuraaville muuttujille: tarinan sisältö kertomuskieliopin mukaisesti pisteytettynä, tarinan hahmojen esittely ja lauserakenteiden monipuolisuus. Viimeisin kategoria jakaantuu tarkempiin alaluokkiin, kuten kommunikaatioyksikön keskipituuteen, eri sanojen määrään ja kaikkien sanojen määrään. Englanninkielisiä viitearvoja ei voi soveltaa suoraan suomen kieleen, sillä kielten eroavaisuuksien vuoksi erityisesti lingvistiset muuttujat, kuten esimerkiksi sanamäärä, ovat varsin erilaisia. Myös sisällön ilmentämisessä voi olla joitain kulttuuri- tai kielikohtaisia eroavaisuuksia (esim. Gagné \& Crago, 2010; Minami 2011), minkä vuoksi testin toimivuus suomalaisessa ympäristössä on tarpeen tutkia, ennen kuin testiä voidaan käyttää kliinisessä työssä arviointivälineenä. Tässä tutkimuksessa suomenkielisestä kerronta-aineistosta on analysoitu ainoastaan tarinan sisältö (story grammar, SG) ja kaikkien tuotettujen sanojen kokonaismäärä (total number of words, TNW). Nämä muuttujat on kuvattu yksityiskohtaisemmin alla. Tähän ratkaisuun päädyttiin siitä syystä, että muun muassa lauserakenteiden monipuolisuuden tai ilmauksen keskipituuden ei ole todettu ilmentävän kehitystä erityisen hyvin kerronta-aineistossa (Mäkinen, 2014). ENNI-testissä tarinan hahmojen esittelyn arviointi pohjautuu englannin kielen määräisen ja epämääräisen artikkelin ilmentämiseen, eikä vastaavaa ilmiötä esiinny suomen kielessä. Aiempi tutkimus on myös osoittanut, että kokonaissanamäärä ja eri sanojen määrä korreloivat voimakkaasti keskenään (esim. Fey ym., 2004; Justice ym., 2006; Mäkinen, Loukusa, Nieminen ym., 2014), minkä vuoksi ne todennäköisesti suurelta osin mittaavat samaa ilmiötä. Tässä tutkimuksessa tarkastelun kohteeksi valittiin kokonaissanamäärä, koska sen laskeminen on eri sanojen määrään verrattuna nopeampi ja yksinkertaisempi toteuttaa kliinisen työn näkökulmasta.

\section{Kertomuksen sisältö (SG)}

ENNI-testin kertomuksen juoni on laadittu siten, että se noudattaa Steinin ja Glennin (1979) kertomuskielioppia ja myös pisteytys perustuu tähän malliin. Schneiderin ym. (2005) mukaan alkusysäys, toiminta ja tulos ovat tarinan kulun kannalta oleellisimpia kertomuskielioppikategorioita ${ }^{2}$, minkä vuoksi niistä annetaan kaksi pistettä. Muiden kertomuskielioppikategorioiden (hahmot, asetelma, reaktio, sisäinen vastaus, sisäinen suunnitelma) ilmentämisestä saa yhden pisteen. Maksimipistemäärä on 37. Liitteessä 1 on esitetty suomenkielinen pisteytyslomake, joka on käännetty englannista ensimmäisen kirjoittajan toimesta ja käännöksen luotettavuuden tarkistamiseksi lomake käännettiin takaisin englanniksi. Käännöstyön jälkeen lomaketta on hieman tarkennettu englanninkieliseen lomakkeeseen verrattuna. Esimerkiksi pisteyttämistä helpottamaan lomakkeeseen on lisätty kohtaan Sisäinen suunnitelma väittämät ihmettelee/hämmästelee, jotka voidaan hyväksyä pisteytettäviksi elementeiksi. Tehdyistä muutoksista on keskusteltu testintekijän professori Schneiderin kanssa.

Pääsääntönä ENNIn sisällön pisteyttämisessä voidaan mainita, että pisteytykseen riittää, jos "joku tekee jotain" ja tämä on kerrontakontekstissa ymmärrettävä. Synonyymiset ilmaukset hyväksytään. Viittaussuhteen tarinan hahmoon tai tapahtumaan ei tarvitse olla tarkka. Hahmojen mainitseminen missä tahansa tarinan vaiheessa on hyväksyttävää, muuten tarinan elementit tulee tuottaa loogisessa järjestyksessä. Kerronnan analyysissa

2 Alkusysäys käynnistää tarinan tapahtumat ja aiheuttaa päähenkilössä ajatuksia ja tunteita (=sisäinen vastaus), jonka seurauksena päähenkilö laatii toimintasuunnitelman (=sisäinen suunnitelma). Tarinan ongelmaa koitetaan ratkaista toiminnan avulla, jonka seurauksena ongelman ratkaisussa onnistutaan tai epäonnistutaan (=tulos). Tulos aiheuttaa päähenkilössä jonkin reaktion. 
täysin yksityiskohtaisia pisteytyskriteereitä on mahdotonta antaa, koska jokainen kertomus on omanlaisensa. Esimerkiksi reaktioiksi voidaan hyväksyä mikä tahansa tarinan kulun kannalta järkevä tulokseen liittyvä hahmojen reaktio, vaikka tätä ei olisikaan mainittu pisteytyslomakkeessa. Ennen pisteyttämistä on kuitenkin hyvä tutustua ENNIn verkkosivuilla kuvattuihin yleisiin pisteytysohjeisiin ja myös liitteessä 2 annettuun suomenkieliseen pisteytysesimerkkiin.

\section{Kertomuksen produktiivisuus (TNW)}

Kerronnan produktiivisuutta eli tuotetun puhunnoksen määrää voidaan analysoida monin tavoin, mutta helpointa lienee tarkastella tuotettujen sanojen kokonaismäärää. Kokonaissanamäärän laskeminen on yksinkertaista, sillä kaikki kertomuksessa esiintyneet sanat lasketaan yhteen. Kertomusten (ja yleensä spontaanipuheen) analysoinnissa ja litteroinnissa on kuitenkin muutamia huomionarvoisia seikkoja (ks. esim. MacWhinney 2000). Sanamäärälaskujen ulkopuolelle jätetään väärät aloitukset ja itse tehdyt korjaukset (<lento heli> lentokone meni vetteen), suorat toistot (<tuo > tuo kiraffioli tosi vihanen), keskeneräiset ilmaukset (sitte se ot...) ja täytesanat ( mmm, tuota, niin, kato). Analyysiin ei myöskään huomioida tutkijalle esitettyjä kysymyksiä tai kommentteja eikä tarinan lopetusfraasia (loppu, sen pituinen se). Kahdeksi sanaksi lasketaan yhteenliittymät, kuten niinku (niin kuin), eikä (ja ei) ja ettei (että ei). Mikäli suurin osa ilmauksen sanoista jää epäselviksi, ilmausta ei analysoida. Jos vain osa ilmauksesta on epäselvää ja sanahahmo kuultavissa, epäselvä sana voidaan sisällyttää analyysiin (se beittää $x x=$ sitä?).

\section{Luotettavuus ja tilastollinen analyysi}

Pisteytyksen luotettavuuden varmistamisek- si toinen tutkija pisteytti $10 \%$ litteraateista. Tutkijoiden välinen luotettavuus tarinan sisällön osalta oli korkea (intraclass correlation coefficient, ICC $=0.94)$. Sanamäärien osalta luotettavuutta ei laskettu, sillä ne saatiin litterointiin käytetyn CLAN-ohjelman (MacWhinney, 2000) avulla automaattisesti. Tilastolliset analyysit suoritettiin IBM SPSS 24 -ohjelmalla. Ikäryhmien välisessä vertailussa käytettiin yksisuuntaista varianssianalyysia (ANOVA) ja efektikoko laskettiin käyttäen etan osittaisneliötä $\left(\eta_{\mathrm{p}}{ }^{2}\right)$. Ikäryhmien parittaiset vertailut suoritettiin Tukeyn testillä ja sukupuolten välistä eroa koko aineistossa tutkittiin t-testillä. SLI- ja ASD-lasten ENNItestin tulosten tarkastelussa käytettiin t-testiä ja efektikoot laskettiin Cohenin $d:$ n avulla. Cohenin (1988) mukaan $d$ voidaan tulkita seuraavasti: 0,2 viittaa pieneen vaikutukseen, 0,5 kohtalaiseen, 0,8 suureen ja 1,3 erittäin suureen vaikutukseen. Lisäksi haluttiin tarkastella ENNI-testin kykyä erotella SLI- ja ASD-lapset tyypillisesti kehittyneistä verrokeistaan. Tähän tarkasteluun käytettiin ROC-käyrää (Bland, 2015). AUC-arvo (area under curve) kertoo todennäköisyyden, jolla tutkittava tunnistetaan kuuluvaksi tiettyyn ryhmään.

\section{TULOKSET}

\section{Tyypillisesti kehittyneet lapset}

Tutkittavien suoriutuminen ikäryhmittäin tarinan sisällön ja kokonaissanamäärän osalta on kuvattu tilastollisten tunnuslukujen avulla taulukossa 2. Ikäryhmien välinen vertailu varianssianalyysin avulla osoitti, että ikäryhmien ENNI-testin sisällön (SG) pistemäärät erosivat tilastollisesti merkitsevästi toisistaan $\left(F(4,166)=32,19, p<0,001, \eta_{\mathrm{p}}{ }^{2}=\right.$ $0.47)$. Parittaisten vertailujen (Tukeyn testi) perusteella 4 - ja 5-vuotiaat erosivat tilastollisesti merkitsevästi $(p<0.05)$ toisistaan ja 
vanhemmista ikäryhmistä, kun taas 6-, 7- ja 8 -vuotiaiden välisessä suoriutumisessa ei havaittu eroa. Tytöt (ka: 22,9 pistettä, kh: 6,0 pistettä) suoriutuivat keskimäärin hieman paremmin ENNI-testistä kuin pojat (ka: 21,7 pistettä, kh: 6,2), mutta sukupuolten välinen ero ei ollut $t$-testin perusteella tilastollisesti merkitsevä $(t(169)=-1,33, p=0,18,95 \%$ luottamusväli $-3,1 ; 0,6, d=0.20)$.

Ikäryhmien välisessä vertailussa varianssianalyysin avulla tilastollisesti merkitsevä ero havaittiin myös kokonaissanamäärän
(TNW) osalta $(F(4,166)=5,82, p<0,001$, $\left.\eta_{\mathrm{p}}{ }^{2}=0.12\right)$. Parittaiset vertailut Tukeyn menetelmällä osoittivat, että 4-vuotiaat kertoivat lyhempiä kertomuksia $(p<0.05)$ kuin 7 - ja 8-vuotiaat, mutta muiden ikäryhmien välillä ei havaittu eroa. Tytöt (ka: 107,8 sanaa, kh: 58,5) kertoivat keskimäärin hieman pidempiä tarinoita kuin pojat (ka: 94,6 sanaa, kh: 33,5), mutta sukupuolten välinen ero ei ollut $t$-testin perusteella tilastollisesti merkitsevä $(t(169)$ $=-1,81, p=0,07,95 \%$ luottamusväli -27,6; $1,18, d=0.28)$.

Taulukko 2. Tyypillisesti kehittyneiden lasten suoriutuminen ENNI-testissä.

\begin{tabular}{|l|l|l|l|l|l|l|}
\hline $\begin{array}{c}\text { Ikä- } \\
\text { ryhmä }\end{array}$ & $\begin{array}{c}\text { keski- } \\
\text { arvo }\end{array}$ & $\begin{array}{c}\text { keski- } \\
\text { hajonta }\end{array}$ & $\begin{array}{c}\text { vaihtelu- } \\
\text { väli }\end{array}$ & $\begin{array}{c}\text { keski- } \\
\text { arvo }\end{array}$ & $\begin{array}{c}\text { keski- } \\
\text { hajonta }\end{array}$ & $\begin{array}{c}\text { vaihtelu- } \\
\text { väli }\end{array}$ \\
\hline 4 vuotta & $13,8^{\text {abcd }}$ & 6,3 & $0-25$ & $71,8^{\text {ab }}$ & 30,5 & $15-148$ \\
\hline 5 vuotta & $20,8^{\text {aefg }}$ & 5,3 & $10-28$ & 92,2 & 31,6 & $52-163$ \\
\hline 6 vuotta & $24,6^{\text {be }}$ & 3,8 & $13-31$ & 101,7 & 37,5 & $43-190$ \\
\hline 7 vuotta & $25,3^{\text {cf }}$ & 3,4 & $16-31$ & $119,4^{\text {a }}$ & 53,4 & $52-287$ \\
\hline 8 vuotta & $25,4^{\text {dg }}$ & 3,1 & $16-29$ & $117,5^{\mathrm{b}}$ & 66,2 & $39-384$ \\
\hline
\end{tabular}

SG = Story grammar, tarinan sisältö; TNW= total number of words, kokonaissanamäärä

Huom! Kolumnin sisällä oleva sama yläindeksi viittaa ryhmien väliseen tilastollisesti merkitsevään eroon (Tukeyn testi, $p<0,05$ ).

\section{Lapset, joilla on SLI tai ASD}

ENNI-testin kykyä erotella ne lapset, joilla on vaikeuksia kielellis-kommunikatiivisissa taidoissaan, arvioitiin vertaamalla SLI- ja ASD-lasten suoriutumista tyypillisesti kehittyviin verrokkeihin. SLI-, ASD- ja verrokkilasten ENNI-testin tilastolliset tunnusluvut tarinan sisällön ja kokonaissanamäärän osalta on kuvattu taulukossa 3. SLI-lapset kertoivat $t$-testin perusteella sisällöllisesti tilastollisesti merkitsevästi niukempia tarinoita kuin tyypillisesti kehittyneet ikätoverinsa $(t(36)$ $=-3,12, p=0,003,95 \%$ luottamusväli -8,2; $-1,9, d=1,13)$. Myös ASD-lasten kohdalla tulokset osoittivat samaa $(t(30)=-3,34, p$ $=0,002,95 \%$ luottamusväli $-10,1 ;-2,4, d=$ $1,18)$. Tarinan kokonaissanamäärän osalta SLI-lasten suoriutuminen oli $t$-testin perusteella niukempaa kuin verrokkilapsilla $t(36)$ $=-3,87, p<0,001,95 \%$ luottamusväli -57,2; $-17,9, d=1,26)$, mutta eroa ei havaittu ASDja verrokkilasten osalta $t(30)=-1,45, p=0,16$, $95 \%$ luottamusväli $-46 ; 7,7, d=0,51$ ). 
Taulukko 3. SLI-, ASD- ja verrokkilasten suoriutuminen ENNI-testissä.

\begin{tabular}{|c|c|c|c|c|c|c|}
\hline & \multicolumn{3}{|c|}{$S G$} & \multicolumn{3}{|c|}{ TNW } \\
\hline Tutkittavat & $\begin{array}{l}\text { keski- } \\
\text { arvo }\end{array}$ & $\begin{array}{c}\text { keski- } \\
\text { hajonta }\end{array}$ & $\begin{array}{l}\text { vaihtelu- } \\
\text { väli }\end{array}$ & $\begin{array}{l}\text { keski- } \\
\text { arvo }\end{array}$ & $\begin{array}{c}\text { keski- } \\
\text { hajonta }\end{array}$ & $\begin{array}{c}\text { vaihtelu } \\
\text { väli }\end{array}$ \\
\hline SLI & $18,0^{a}$ & 4,9 & $6-27$ & $63,5^{a}$ & 25,6 & $22-129$ \\
\hline SLI-verrokit & $23,5^{a}$ & 4,8 & $8-28$ & $101,0^{a}$ & 33,6 & 55-165 \\
\hline ASD & $18,9^{b}$ & 6,6 & $4-27$ & 83,9 & 41,6 & 19-161 \\
\hline ASD-verrokit & $25,2^{b}$ & 3,6 & $19-32$ & 103,0 & 32,3 & $67-171$ \\
\hline
\end{tabular}

$S G=$ Story grammar, tarinan sisältö; $T N W=$ total number of words, kokonaissanamäärä

Huom! Kolumnin sisällä oleva sama yläindeksi viittaa ryhmien väliseen tilastollisesti merkitsevään eroon (t-testi, $p<0,05$ ).

Koska sekä SLI- että ASD-lasten kertomukset olivat sisällöllisesti verrokkeja niukempia, haluttiin ENNI-testin erottelukykyä sisällön osalta tarkastella tarkemmin. Tätä varten tehtiin erotteluanalyysi ROC-käyrien avulla. Tulokset osoittivat, että ENNI-testin

\section{Kuva 1. ENNI-testin tarinan}

sisältöpisteiden erottelukyky SLI- ja verrokkilasten osalta.

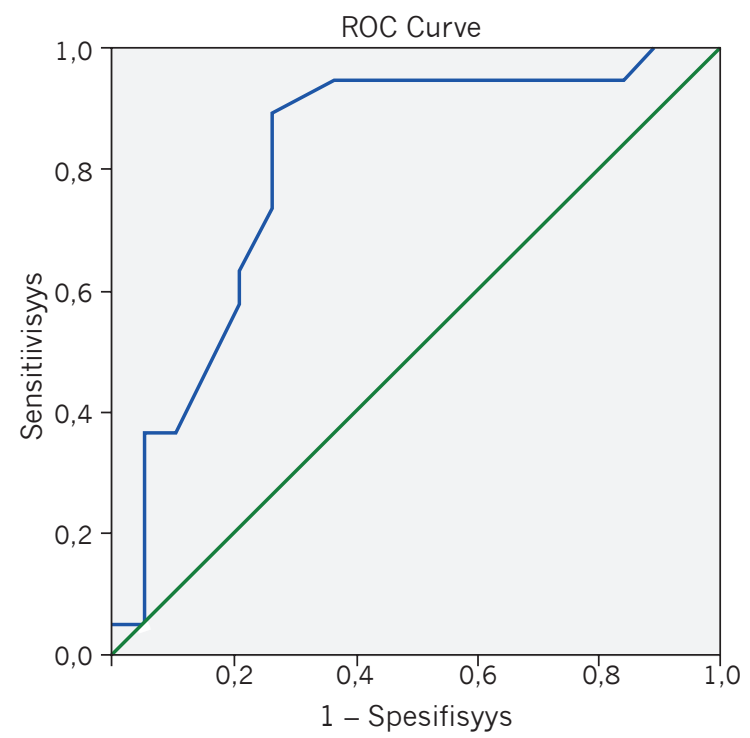

erottelukyky SLI-lasten (kuva 1) ja ASDlasten (kuva 2) osalta oli hyvä (SLI: AUC $=0.81$, keskivirhe $=0,075, p=0,001,95 \%$ luottamusväli 0,664-0,957; ASD: AUC = 0.80 , keskivirhe $=0,077, p=0.003,95 \%$ luottamusväli 0,652-0,954).

Kuva 2. ENNI-testin tarinan sisältöpisteiden erottelukyky ASD-ja verrokkilasten osalta.

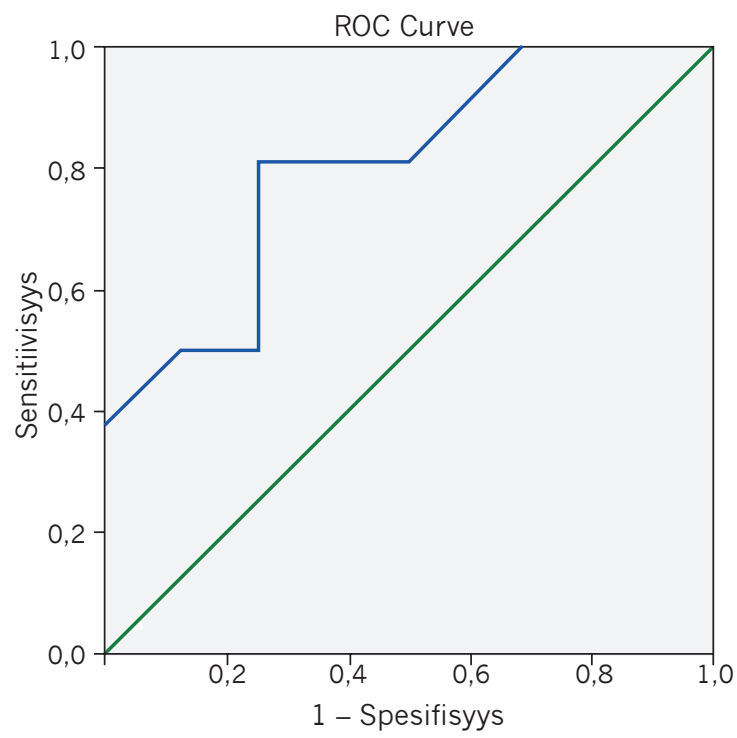




\section{POHDINTA}

Tässä tutkimuksessa tarkasteltiin ENNItestin (Schneider ym., 2005) avulla 4-8-vuotiaiden lasten kerrontataitoja ja testin soveltuvuutta erottelemaan ne lapset, joilla on kielellis-kommunikatiivisia vaikeuksia, tyypillisesti kehittyvistä verrokeistaan. Tulosten perusteella tyypillisesti kehittyvien lasten kerrontataidot kehittyvät iän myötä, sillä vanhemmat lapset kertoivat sisällöllisesti runsaampia tarinoita kuin nuoremmat lapset. Erityisesti kehitys näkyy 4 ja 5 ikävuoden ja 5 ja 6 ikävuoden välillä. Sitä vanhempia lapsia ENNI ei enää erottele toisistaan. Tulokset ovat vastaavia muiden tutkimusten kanssa (esim. Khan ym., 2016; Mäkinen, Loukusa, Nieminen ym., 2014; Price ym., 2006), mikä osoittaa kerrontataidoissa tapahtuvan huomattavaa kehitystä ennen kouluikää. Myös englanninkielisessä aineistossa ENNIn on todettu mittaavan kehitystä parhaiten nuoremmissa ikäryhmissä (Schneider ym., 2006). Tyttöjen ja poikien välisessä suoriutumisessa ei ollut eroa, minkä vuoksi ENNIn viitearvoja voidaan käyttää sukupuolesta riippumatta. Sukupuolen ei ole todettu vaikuttavan kerronnan sisältöön muissakaan tutkimuksissa (Fernandez, 2013; Price ym., 2006; Rajala \& Eriksson, 2014), joskin Feyn ym. (2004) tutkimuksessa tytöt kertoivat sisällöllisesti laadukkaampia tarinoita kuin pojat.

Kertomuksen produktiivisuuden eli tuotettujen sanojen kokonaismäärän osalta tulokset ovat yhteneviä aiemman kirjallisuuden kanssa ja osoittavat iän myötä tapahtuvaa kehitystä (Justice ym., 2006; Mäkinen, Loukusa, Nieminen ym., 2014; Westerveld ym., 2004). Neljävuotiaat kertoivat selvästi lyhempiä kertomuksia kuin 7- ja 8-vuotiaat lapset, mutta muiden ikäryhmien väliltä ei löydetty tilastollista eroa. Myös alkuperäisessä ENNI-testissä 4-vuotiaiden tarinat olivat muita ikäryhmiä lyhyempiä (Schneider ym.,
2005), mutta kielikohtaisten erojen vuoksi tämän tutkimuksen tuloksen heijastaminen alkuperäistestiin kokonaissanamäärän osalta on haastavaa. Tyttöjen ja poikien tarinoissa ei ollut pituuden suhteen tilastollista eroa, vaikka tytöt kertoivat keskimäärin hieman pidempiä tarinoita. Sen sijaan Fernandezin (2013) tutkimuksessa tytöt tuottivat tilastollisesti merkitsevästi pidempiä tarinoita kuin pojat. Myös Fey ym. (2004) havaitsivat saman tutkimuksessaan. On huomattava, että sanamäärien suhteen kertomukset olivat kokonaisuudessaan hyvin vaihtelevia. Tuotetun sanamäärän on todettu selittävän tarinan sisältöä (Mäkinen, Loukusa, Nieminen ym., 2014, ks. myös Fernandez, 2013; Soodla \& Kikas 2011), mutta pitkä tarina ei suinkaan ole tae hyvästä kertomuksesta tai relevantista tarinan sisällöstä (ks. esim. Berman \& Slobin 1994; Mäkinen, 2014).

Lapset, joilla on SLI, tuottivat verrokkilapsia niukempia tarinoita sekä sisällöllisesti että pituuden suhteen tarkasteltuna. Tulokset ovat vastaavia muiden tutkimusten kanssa (Fey ym., 2004; Duinmeijer ym., 2012; Mäkinen, Loukusa, Laukkanen., 2014; Norbury ym., 2013), mikä osoittaa kerronnan olevan varsin vaativaa lapsille, joilla on kielellisiä vaikeuksia. Aiempien tutkimusten mukaan kerronnan vaikeudet ovat yhteydessä SLI-lasten myöhempään kielelliseen suoriutumiseen ja oppimistaitoihin (ks. esim. Botting, Faragher, Simkin, Knox \& Conti-Ramsden 2001), minkä vuoksi kerronnan tarkastelun tulisi kuulua näiden lasten puheterapeuttiseen arviointiin ja kuntoutukseen. Myös lapset, joilla on ASD, tuottivat ikätovereitaan niukempia kertomuksia tarinan sisällön suhteen tarkasteltuna. Autismikirjon osalta aiemmat tutkimustulokset ovat olleet hieman vaihtelevia, sillä osassa tutkimuksissa relevantin informaatiosisällön tuottamisen on todettu olevan heille haastavaa (Mäkinen, Loukusa, Leinonen ym., 2014; Rumpf, Kamp-Becker, 
Becker \& Kauschke, 2012; Suh ym., 2014; ks. myös Baixauli ym., 2016), kun taas osassa tutkimuksia vastaavaa eroa ei ole löydetty (Losh \& Gordon, 2014; Norbury \& Bishop, 2003; Norbury ym., 2013). Tässä tutkimuksessa tuotettujen sanojen kokonaismäärä ei eronnut autismikirjon ja verrokkilasten osalta (ks. myös Mäkinen, Loukusa, Leinonen ym., 2014; Norbury \& Bishop, 2003; Suh ym., 2014). Tämä osoittaa autismikirjon lasten kertomusten produktiivisuuden olevan samankaltaista kuin verrokeilla, mutta se, mitä kerrottiin, ei välttämättä ollut tarinan kulun kannalta täysin relevanttia. Toisaalta osassa tutkimuksia on huomattu, että autismikirjon lapset tuottavat produktiivisuuden suhteen niukempia tarinoita (ks. Baixauli ym., 2016).

Suuren hajonnan ja melko pienen otoskoon vuoksi tämän tutkimuksen tuloksia tulee tarkastella varauksella. Erityisesti SLI- ja ASDlasten aineistot olivat pieniä, mikä tulee huomioida tulosten tulkinnassa. Suuri hajonta on kerronnalle tyypillinen ominaisuus (esim. Justice ym., 2006; Mäkinen, 2014; Norbury \& Bishop, 2003), mutta se on voinut vaikeuttaa ryhmien välisten tilastollisten erojen ilmenemistä näin pienessä otoksessa. Suuren hajonnan vuoksi tässä tutkimuksessa annettujen tilastollisten tunnuslukujen käyttöön lasten kerrontataitojen arvioinnissa on suhtauduttava hyvin varoen. Tässä tutkimuksessa kertomuksia analysoitiin kvantitatiivisesti, mutta jatkossa olisi tarpeen huomioida myös laadullisempi näkökulma ja kuvata niitä keskeisiä elementtejä, joissa kerronnan vaikeuksia on havaittu.

Vaikka ENNI-testin validiteettia ja reliabiliteettia on tutkittu englannin kielessä (Schneider ym., 2006, ks. myös Schneider ym., 2005), tulisi sen psykometrisia ominaisuuksia kartoittaa tulevaisuudessa tarkemmin myös suomen kielessä. Näyttää kuitenkin siltä, että erityisesti pienten lasten arviointiin ENNI-testin sisällön muuttuja on melko toimiva mittari, ja tämä muuttuja myös erottelee SLI- ja ASD-lapset tyypillisesti kehittyvistä lapsista. Myös Schneider ym. (2005) havaitsivat ENNIn olevan toimiva mittari tunnistamaan lapset, joilla on SLI. Kerronnan vaikeudet ovat tyypillisiä kielellisessä erityisvaikeudessa ja autismikirjossa, mutta ne kuuluvat myös uuteen sosiaalis-pragmaattiseen kommunikointihäiriöön (social (pragmatic) communication disorder), joka sisältyy Amerikan psykiatrisen yhdistyksen tautiluokituksessa (DSM-5) kuvattuun kommunikaatiohäiriöiden alaluokkaan (American Psychiatric Association, 2013). Vastaava diagnoosi näyttäisi sisältyvän myös 2018 julkaistavaan WHO:n ICD-11 tautiluokitukseen (World Health Organization, 2016). Sosiaalis-pragmaattisen kommunikointihäiriön tunnistamisessa puheterapeuttien rooli on ensiarvoisen tärkeä ja työkaluja lasten pragmaattisen kielen, mukaan lukien kerronnan, arviointiin tarvitaan ehdottomasti lisää. ENNI-testi voi kerronnan osalta paikata tätä puutetta ja auttaa tunnistamaan ne lapset, joiden kerrontaa tulisi kuntouttaa. Kerronnan kuntoutustutkimuksia on julkaistu vielä niukasti, mutta muutamien tutkimustulosten perusteella kerronnan kuntoutuksen on todettu olevan tuloksellista kielellisissä vaikeuksissa (Gillam \& Gillam, 2016; ks. myös Suvanto, 2012) ja autismikirjossa (Gillam, Hartzheim, Studenka, Simonsmeier \& Gillam, 2015). Kaiken kaikkiaan on kuitenkin muistettava, että kerrontaa tulisi arvioida monipuolisesti käyttäen erilaisia menetelmiä. Lisäksi on ensiarvoisen tärkeää keskustella lapsen lähi-ihmisten kanssa siitä, vastaavatko testeissä saadut kerronnan tulokset lapsen arkielämän kerronnan taitoja.

\section{KIITOKSET}

Kiitokset avusta aineistonkeruussa logopedian opiskelijoille, nyt jo valmistuneille puheterapeuteille Ilona Haataja, Meeri Nur- 
mimäki, Anniina Ruohomäki, Katja Saarinen, ja Kaisa Tervahauta. Kiitos yhteistyöstä kaikille kouluille ja päiväkodeille. Kiitokset OYS:n audiofoniatrian, lasten neurologian ja lastenpsykiatrian yksiköille avusta tutkimushenkilöiden tavoittamisessa. Kiitos FM Anna-Kaisa Toloselle luotettavuuslaskujen suorittamisesta. Kiitokset professori Schneiderille yhteistyöstä ja avusta ENNIn pisteytykseen liittyvissä kysymyksissä. Suurimmat kiitokset tutkimukseen osallistuneille lapsille ja heidän perheilleen. Tätä tutkimusta ovat rahoittaneet Aivosäätiö, Oulun yliopiston tukisäätiö, Oulun yliopiston humanistinen tiedekunta, Stiftelsen Alma och K. A. Snellman Säätiö, Suomen Akatemia ja Suomen Kulttuurirahasto.

\section{LÄHDEVIITTEET}

American Psychiatric Association. (2013). Diagnostic and statistical manual of mental disorders (5th ed.). Washington: American Psychiatric Association.

Baixauli, I., Colomer, C., Roselló, B. \& Miranda, A. (2016). Narratives of children with highfunctioning autism spectrum disorder: a metaanalysis. Research in Developmental Disabilities, 59, 234-254.

Berman, R. A. \& Slobin, D. I. (1994). Narrative structure. Teoksessa R. A. Berman \& D. I. Slobin (toim.), Relating events in narrative. $A$ crosslinguistic developmental study (s. 39-84). Hillsdale: Lawrence Erlbaum.

Bishop, D.V.M. (2004). Expression, reception and recall of narrative instrument. ERRNI Manual. Lontoo: Harcourt Assessment.

Bland, M. (2015). An introduction to medical statistics. (4th ed.). Oxford: Oxford University Press.

Botting, N., Faragher, B., Simkin, Z., Knox, E. \& Conti-Ramsden, G. (2001). Predicting pathways of specific language impairment: What differentiates good and poor outcome? Journal of Child Psychology and Psychiatry, 42, 1013-1020.

Cohen, J. (1988). Statistical power analysis for the behavioural sciences. Mahwah: Lawrence Erlbaum Associates.

Duinmeijer, I., de Jong, J. \& Scheper, A. (2012). Narrative abilities, memory and attention in children with a specific language impairment. International Journal of Communication and Language Disorders, 47, 542-555.

Eriksson, P. \& Rajala, E. (2014). Miten kielellisesti tyypillisesti kehittyneet 6-7-vuotiaat lapset tuottavat ja ymmärtävät Sammakkotarinan? Alustavat ikänormit. Pro gradu tutkielma. Tampereen yliopisto.

Fernandez, C. (2013). Mindful storytellers: Emerging pragmatics and theory of mind development. First Language, 33, 20-46.

Fey, M.E., Catts, H.W., Proctor-Williams, K., Tomblin, B. \& Zhang, X. (2004). Oral and written story composition skills of children with language impairment. Journal of Speech, Language, and Hearing Research, 47, 13011318.

Gagarina, N., Klop, D., Kunnari, S., Tantele, K., Välimaa, T., Balciuniene, I., Bohnacker, U. \& Walters, J. (2012). Part I. MAIN: Multilingual Assessment Instrument for Narratives. ZAS Papers in Linguistics 56. Berlin: ZAS.

Gagné, A. \& Crago, M. (2010). The use of the ENNI to assess story grammar competency of school-aged French speaking children with and without specific language impairment. Canadian Journal of Speech-Language Pathology and Audiology, 34, 231-245.

Gillam, S. \& Gillam, R. B. (2016). Narrative discourse intervention for school-aged children with language impairment. Topics in Language Disorders, 36, 20-34.

Gillam, S.L., Hartzheim, D., Studenka, B., Simonsmeier, V. \& Gillam, R. (2015). Narrative intervention for children with autism spectrum disorder (ASD). Journal of Speech, Language, and Hearing Research, 58, 920-933.

Hakala, S. (2013). "Ai kerronks mää nyt jotain?" Viisivuotiaiden lasten tarinankerronnan taidot. NMI Bulletin, 2, 19-40.

Huttunen, K. \& Ryder, N. (2012). How children with normal hearing and children with a cochlear implant use mentalizing vocabulary and other evaluative expressions in their narratives. Clinical Linguistics \& Phonetics, 26, 823-844. 
Justice, L.M., Bowles, R.P., Kaderavek, J.N., Ukrainetz, T.A., Eisenberg, S.L. \& Gillam, R.B. (2006). The index of narrative microstructure: A clinical tool for analyzing school-aged children's narrative performances. American Journal of Speech-Language Pathology, 15, 177-191.

Khan, K.S., Gugiu, M.R., Justice, L.M., Bowles, R.P., Skibbe, L.E. \& Piasta, S.B. (2016). Agerelated progressions in story structure in young children's narratives. Journal of Speech, Language, and Hearing Research, 59, 1395-1408.

Kunnari, S., Välimaa, T. \& Laukkanen-Nevala, P. (2016). Macrostructure in the narratives of monolingual Finnish and bilingual FinnishSwedish children. Applied Psycholinguistics, 37, 123-144.

Lahtinen, J. (1997). Bus Story narratiivisena tutkimusmenetelmänä. Pro gradu tutkielma. Oulun yliopisto.

Leinonen, E., Letts, C. \& Rae Smith, B. (2000). Children's pragmatic communication disorders. Lontoo, UK: Whurr Publishers.

Lepola, J., Peltonen, M. \& Korpilahti, P. (2009). Kuvakertomus 4-vuotiaiden tarinan ymmärtämisen arvioinnissa. Pube ja kieli, 29, 121-143.

Losh, M. \& Gordon, P.C. (2014). Quantifying narrative ability in autism spectrum disorder: A computational linguistic analysis of narrative coherence. Journal of Autism and Developmental Disorders, 44, 3016-3025.

MacWhinney, B. (2000). The CHILDES project: Tools for analyzing talk. Mahwah: Erlbaum.

Mavis, I., Tunçer, M. \& Gagarina, N. (2016). Macrostructure components in narrations of Turkish-German bilingual children. Applied Psycholinguistics, 37, 69-89.

Mayer, M. (1969). Frog, where are you? New York: Dial Books.

Minami, M. (2011). Telling stories in two languages: Multiple approaches to understanding English-Japanese bilingual children's narratives. Charlotte: Information Age Publishing.

Mäkinen, L. (2014). Narrative language in typically developing children, children with specific language impairment and children with autism spectrum disorder. Väitöskirja. Oulun yliopisto. Acta Universitatis Ouluensis. B Humaniora 124.

Mäkinen, L., Loukusa, S. \& Kunnari, S. (2016).
Kuvasarjakerronnan ja kielellisen työmuistin välinen yhteys tyypillisesti kehittyneillä lapsilla ja lapsilla, joilla on kielellinen erityisvaikeus. Puhe ja kieli, 36, 33-44.

Mäkinen, L., Loukusa S., Laukkanen, P., Leinonen, E. \& Kunnari, S. (2014). Linguistic and pragmatic aspects of narration in Finnish typically developing children and children with specific language impairment. Clinical Linguistics and Phonetics, 28, 413-427.

Mäkinen, L., Loukusa, S., Leinonen, E., Moilanen, I., Ebeling H. \& Kunnari S. (2014). Characteristics of narrative language in autism spectrum disorder: Evidence from the Finnish. Research in Autism Spectrum Disorders, 8, 987-996.

Mäkinen, L., Loukusa, S., Nieminen, L., Leinonen, E. \& Kunnari, S. (2014). The development of narrative productivity, syntactic complexity, referential cohesion, and event content in fourto eight-year-old Finnish children. First Language, 34, 24-42.

Norbury, C.F. \& Bishop, D.V.M. (2003). Narrative skills of children with communication impairments. International Journal of Language, and Communication Disorders, 38, 287-313.

Norbury, C.F., Gemmel, T. \& Paul, R. (2013). Pragmatic abilities in narrative production: A cross-disorder comparison. Journal of Child Language, 41, 485-510.

Price, J.R., Roberts, J.E. \& Jackson, S.C. (2006). Structural development of the fictional narratives of African American preschoolers. Language, Speech, and Hearing Services in Schools, 37, 178-190

Renfrew, C. (1997). Bus Story Test. Milton Keynes: Speechmark.

Rumpf, A-L., Kamp-Becker, I,, Becker, K. \& Kauschke, C. (2012). Narrative competence and internal state language of children with Asperger Syndrome and ADHD. Research in Developmental Disabilities, 33, 1395-1407.

Schneider, P. (1996). Effects of pictures versus orally presented stories on story retellings by children with language impairments. American Journal of Speech-Language Pathology, 5, 86-96.

Schneider, P. \& Dubé, R.V (2005). Story presentation effects on children's retell content. American Journal of Speech-Language Pathology, 14, 52-60. 
Schneider, P. Dubé R.V. \& Hayward, D. (2005). The Edmonton Narrative Norms Instrument. Saatavissa: www.rehabmed.ualberta.ca/ spa/enni.

Schneider, P., Hayward, D. \& Dubé, R.V. (2006). Storytelling from pictures using the Edmonton Narrative Norms Instrument. Journal of Speech-Language Pathology and Audiology, 30, 224-238.

Soodla, P. \& Kikas, E. (2011). Oral narratives of 6-7 years old Estonian children. Teoksessa Veisson, E. Hujala, M. Waniganayake, P. Smith \& E. Kikas (toim.), Global perspectives in early childhood education: Diversity, challenges and possibilities (s. 217-235). Frankfurt: Peter Lang. Stein, N.L. \& Glenn, C.G. (1979). An analysis of story comprehension in elementary school children. Teoksessa R.O. Freedle (toim.), New directions in discourse processing (s. 113-155). Norwood: Ablex.

Suh, J., Eigsti, IM., Naigles, L., Barton, M., Kelley, E. \& Fein, D. (2014). Narrative performance of optimal outcome children and adolescents with a history of an autism spectrum disorder (ASD). Journal of Autism and Developmental Disorders, 44, 180-193.

Suvanto, A. (2012). Lapsi tarinaa rakentamassa. Kielihäiriöisten lasten kerrontataidot ja niiden kuntoutuminen. Väitöskirja. Oulun yliopisto. Acta Universitatis Ouluensis. B Humaniora B106.

To, K-S. C., Stokes, S.F., Cheung, H-T. \& T'sou, B. (2010). Narrative assessment of Cantonesespeaking children. Journal of Speech, Language, and Hearing Research, 53, 648-669.

Westerveld, M.F., Gillon, G.T. \& Miller, J.F. (2004). Spoken language samples of New Zealand children in conversation and narration. Advances in Speech-Language Pathology, 6, 195-208.

Westerveld, M.F. \& Moran, C. (2013). Spoken expository discourse of children and adolescents: Retelling versus generation. Clinical Linguistics \& Phonetics, 27, 720-734.

World Health Organization, WHO (2016). International Classification of Diseases, $11 \mathrm{th}$ revision (ICD-11). Saatavissa: http://who.int. classifications/icd/evision/en.

Young, E.C., Diehl, J.J., Morris, D., Hyman, S.L. \& Bennetto, L. (2005). The use of two language tests to identify pragmatic language problems in children with autism spectrum disorders. Language, Speech, and Hearing Services in Schools, $36,62-72$. 
Liite 1 Pisteytyslomake

\begin{tabular}{|c|c|c|c|}
\hline Tarinan elementti & Hyväksyttävä vastaus & Piste & \\
\hline Hahmo 1 & $\begin{array}{l}\text { kirahvi/ mies/ poika/ tai mikä tahansa eläin kuten hevonen } \\
\text { (ei hyväksytä pronominia) }\end{array}$ & 0 & 1 \\
\hline Hahmo 2 & $\begin{array}{l}\text { elefantti/ norsu/ nainen/ tyttö/ tai mikä tahansa eläin } \\
\text { kuten lehmä (ei hyväksytä pronominia) }\end{array}$ & 0 & 1 \\
\hline Asetelma & $\begin{array}{l}\text { uima-altaalla/ menossa uimaan/leikkivät/pitää lentokonetta/ } \\
\text { jollakin on lentokone/ pyytää leikkimään }\end{array}$ & 0 & 1 \\
\hline Alkusysäys & $\begin{array}{l}\text { K leikkii lentokoneella/ lennättää lentokonetta/K näyttää / } \\
\text { esittelee E:Ile lentokonetta/ K antaa lentokoneen E:Ile }\end{array}$ & 0 & 2 \\
\hline Sisäinen vastaus & $\begin{array}{l}\text { E haluaa lentokoneen/ on kiinnostunut lentokoneesta/ } \\
\text { ihmettelee/ hämmästelee }\end{array}$ & 0 & 1 \\
\hline Sisäinen suunnitelma & E päättää ottaa lentokoneen & 0 & 1 \\
\hline Toiminta & $\begin{array}{l}\text { E ottaa lentokoneen/ lennättää lentokonetta/ K antaa E:Ile } \\
\text { vuoron }\end{array}$ & 0 & 2 \\
\hline Tulos & $\begin{array}{l}\text { lentokone tippuu altaaseen/ E heittää lentokoneen } \\
\text { altaaseen }\end{array}$ & 0 & 2 \\
\hline Kirahvin reaktio & K on vihainen/ huutaa/ suuttuu/ tuijottaa konetta & 0 & 1 \\
\hline Elefantin reaktio & $\begin{array}{l}\text { E on surullinen/ nolo/ hävettää/ pelästynyt/ tuijottaa } \\
\text { konetta/ sanoo hups }\end{array}$ & 0 & 1 \\
\hline Kummankin reaktio* & ovat surullisia/ riitelevät & 0 & 1 \\
\hline Hahmo 3 & $\begin{array}{l}\text { uimavalvoja/ hengenpelastaja/ toinen elefantti/ toinen } \\
\text { mies/ E:n isä/ veli (ei hyväksytä pronominia) }\end{array}$ & 0 & 1 \\
\hline Alkusysäys & $\begin{array}{l}\text { Hahmo } 3 \text { tulee/ E näkee Hahmo 3:n/ Hahmo } 3 \text { näkee } \\
\text { lentokoneen vedessä/ Hahmo } 3 \text { kysyy mitä on tapahtunut }\end{array}$ & 0 & 2 \\
\hline Sisäinen vastaus & E/K toivoo että Hahmo 3 voi auttaa/ Hahmo 3 haluaa auttaa & 0 & 1 \\
\hline Sisäinen suunnitelma & $\begin{array}{l}\text { E/K päättää kysyä apua/ kertovat mitä on tapahtunut/ } \\
\text { pyytävät Hahmo 3:a hakemaan koneen/ Hahmo } 3 \text { päättää } \\
\text { yrittää Ei hyväksytä: E puhuu Hahmo 3:lle ilman että käy } \\
\text { ilmi mistä }\end{array}$ & 0 & 1 \\
\hline Toiminta & Hahmo 3 yrittää saada koneen/ tavoittelee konetta & 0 & 2 \\
\hline Tulos & Hahmo 3 ei saa konetta/ kone on liian kaukana/ kone uppoaa & 0 & 2 \\
\hline Kirahvin reaktio & K on surullinen/ huolestunut/ itkee/ tuijottaa konetta & 0 & 1 \\
\hline Elefantin reaktio & E on surullinen/ syyllinen/ näyttää nololta/ pyytää anteeksi & 0 & 1 \\
\hline Hahmo3:n reaktio & $\begin{array}{l}\text { Hahmo } 3 \text { on pettynyt/ kohauttaa olkiaan/ sanoo ettei yllä } \\
\text { koneeseen }\end{array}$ & 0 & 1 \\
\hline Kummankin reaktio** & ovat surullisia & 0 & 1 \\
\hline Hahmo 4 & $\begin{array}{l}\text { toinen uimavalvoja/ hengenpelastaja/ toinen nainen/ E:n } \\
\text { äiti/ sisko/ toinen henkilö (ei hyväksytä pronominia) }\end{array}$ & 0 & 1 \\
\hline Alkusysäys & Hahmo 4 tulee & 0 & 2 \\
\hline Sisäinen vastaus & $\begin{array}{l}\text { Hahmo } 4 \text { haluaa auttaa/ tietää miten saa koneen/ tarjoaa } \\
\text { apua }\end{array}$ & 0 & 1 \\
\hline Sisäinen suunnitelma & $\begin{array}{l}\text { Hahmo } 4 \text { päättää yrittää/ on idea/ sanoo hän saa sen/ } \\
\text { E/K/Hahmo } 3 \text { pyytää voiko Hahmo } 4 \text { ottaa lentokoneen }\end{array}$ & 0 & 1 \\
\hline Toiminta & Hahmo 4 ylettyy koneeseen/ yrittää saada/ saa koneen & 0 & 2 \\
\hline Tulos & Hahmo 4 antaa koneen K:Ile/ K:Ila on lentokone & 0 & 2 \\
\hline Kirahvin reaktio & K on iloinen/ innoissaan/ halaa konetta/ sanoo kiitos & 0 & 1 \\
\hline Elefantin reaktio & E on iloinen/ helpottunut/ sanoo kiitos & 0 & 1 \\
\hline Hahmo4:n reaktio & Hahmo 4 on mielissään/ helpottunut & 0 & 1 \\
\hline Kummankin reaktio** & ovat iloisia/ innostuneita/ kavereita/ sanovat kiitos & 0 & 1 \\
\hline
\end{tabular}


Liite 2 Esimerkkikertomus ja testin pisteyttäminen

No tolla kiraffilla on lentsikka.

Ja tuo norsu vaan kattoo.

Ja sitte se norsu sai sen lentsikan kiraffilta.

Ja sitte se heitti sen jokkeen.

$<$ Ja sitte> ja sitte se kiraffi irvisti.

Ja <sitte> sitte tuo tuli toinen possu.

Ja sitte se tuli sen lähelle.

Niin se toinen possu säikähti.

No sitte se yritti ottaa sitä se poikanorsu.

Ja <sitte> sitte sitä kirahvia alko itkettään.

Ja sitte tuli äiti.

Ja sitte se otti haaveen. [= haavin].

Ja $<$ se $>$ se yritti ja yritti.

Ja se sai sen ja anto sen takas kirahville.

Sitten se kirahvi vaan jotenkin niinku [: niin kuin] tuolleen.

91 sanaa, 21 pistettä (ks. lomake) 


\begin{tabular}{|c|c|c|}
\hline Tarinan elementti & Hyväksyttävä vastaus & Piste \\
\hline Hahmo 1 & $\begin{array}{l}\text { kirahvi/ mies/ poika/ tai mikä tahansa eläin kuten hevonen } \\
\text { (ei hyväksytä pronominia) }\end{array}$ & 0 \\
\hline Hahmo 2 & $\begin{array}{l}\text { elefantti/ norsu/ nainen/ tyttö/ tai mikä tahansa eläin } \\
\text { kuten lehmä (ei hyväksytä pronominia) }\end{array}$ & 0 \\
\hline Asetelma & $\begin{array}{l}\text { uima-altaalla/ menossa uimaan/leikkivät/pitää lentokonetta/ } \\
\text { jollakin on lentokone/ pyytää leikkimään }\end{array}$ & (1) \\
\hline Alkusysäys & $\begin{array}{l}\text { K leikkii lentokoneella/ lennättää lentokonetta/K näyttää / } \\
\text { esittelee E:Ile lentokonetta/ K antaa lentokoneen E:lle }\end{array}$ & 2 \\
\hline Sisäinen vastaus & $\begin{array}{l}\text { E haluaa lentokoneen/ on kiinnostunut lentokoneesta/ } \\
\text { ihmettelee/ hämmästelee }\end{array}$ & 0 \\
\hline Sisäinen suunnitelma & E päättää ottaa lentokoneen & 0 \\
\hline Toiminta & $\begin{array}{l}\text { E ottaa lentokoneen/ lennättää lentokonetta/ K antaa E:Ile } \\
\text { vuoron }\end{array}$ & 02 \\
\hline Tulos & $\begin{array}{l}\text { lentokone tippuu altaaseen/ E heittää lentokoneen } \\
\text { altaaseen }\end{array}$ & 0 (2) \\
\hline Kirahvin reaktio & K on vihainen/ huutaa/ suuttuu/ tuijottaa konetta & (1) \\
\hline Elefantin reaktio & $\begin{array}{l}\text { E on surullinen/ nolo/ hävettää/ pelästynyt/ tuijottaa } \\
\text { konetta/ sanoo hups }\end{array}$ & 0 \\
\hline Kummankin reaktio* & ovat surullisia/ riitelevät & 0 \\
\hline Hahmo 3 & $\begin{array}{l}\text { uimavalvoja/ hengenpelastaja/ toinen elefantti/ toinen } \\
\text { mies/ E:n isä/ veli (ei hyväksytä pronominia) }\end{array}$ & 0 \\
\hline Alkusysäys & $\begin{array}{l}\text { Hahmo } 3 \text { tulee/ E näkee Hahmo 3:n/ Hahmo } 3 \text { näkee } \\
\text { lentokoneen vedessä/ Hahmo } 3 \text { kysyy mitä on tapahtunut }\end{array}$ & 0 \\
\hline Sisäinen vastaus & E/K toivoo että Hahmo 3 voi auttaa/ Hahmo 3 haluaa auttaa & 0 \\
\hline Sisäinen suunnitelma & $\begin{array}{l}\text { E/K päättää kysyä apua/ kertovat mitä on tapahtunut/ } \\
\text { pyytävät Hahmo 3:a hakemaan koneen/ Hahmo } 3 \text { päättää } \\
\text { yrittää Ei hyväksytä: E puhuu Hahmo 3:lle ilman että käy } \\
\text { ilmi mistä }\end{array}$ & 0 \\
\hline Toiminta & Hahmo 3 yrittää saada koneen/ tavoittelee konetta & 02 \\
\hline Tulos & Hahmo 3 ei saa konetta/ kone on liian kaukana/ kone uppoaa & 0 \\
\hline Kirahvin reaktio & K on surullinen/ huolestunut/ itkee/ tuijottaa konetta & 011 \\
\hline Elefantin reaktio & E on surullinen/ syyllinen/ näyttää nololta/ pyytää anteeksi & 0 \\
\hline Hahmo3:n reaktio & $\begin{array}{l}\text { Hahmo } 3 \text { on pettynyt/ kohauttaa olkiaan/ sanoo ettei yllä } \\
\text { koneeseen }\end{array}$ & 0 \\
\hline Kummankin reaktio** & ovat surullisia & 0 \\
\hline Hahmo 4 & $\begin{array}{l}\text { toinen uimavalvoja/ hengenpelastaja/ toinen nainen/ E:n } \\
\text { äiti/ sisko/ toinen henkilö (ei hyväksytä pronominia) }\end{array}$ & 0 \\
\hline Alkusysäys & Hahmo 4 tulee & 02 \\
\hline Sisäinen vastaus & $\begin{array}{l}\text { Hahmo } 4 \text { haluaa auttaa/ tietää miten saa koneen/ tarjoaa } \\
\text { apua }\end{array}$ & 0 \\
\hline Sisäinen suunnitelma & $\begin{array}{l}\text { Hahmo } 4 \text { päättää yrittää/ on idea/ sanoo hän saa sen/ } \\
\text { E/K/Hahmo } 3 \text { pyytää voiko Hahmo } 4 \text { ottaa lentokoneen }\end{array}$ & 0 \\
\hline Toiminta & Hahmo 4 ylettyy koneeseen/ yrittää saada/ saa koneen & 02 \\
\hline Tulos & Hahmo 4 antaa koneen K:Ile/ K:Ila on lentokone & (2) \\
\hline Kirahvin reaktio & K on iloinen/ innoissaan/ halaa konetta/ sanoo kiitos & 0 \\
\hline Elefantin reaktio & E on iloinen/ helpottunut/ sanoo kiitos & 0 \\
\hline Hahmo4:n reaktio & Hahmo 4 on mielissään/ helpottunut & 0 \\
\hline Kummankin reaktio** & ovat iloisia/ innostuneita/ kavereita/ sanovat kiitos & 0 \\
\hline
\end{tabular}




\section{PERFORMANCE OF TYPICALLY DEVELOPING CHILDREN, CHILDREN WITH SPECIFIC LANGUAGE IMPAIRMENT, AND CHILDREN WITH AUTISM SPECTRUM DISORDER IN THE EDMONTON NARRATIVE NORMS INSTRUMENT (ENNI)}

Leena Mäkinen, University of Oulu, Research unit of logopedics, Child Language Research Center Soile Loukusa, University of Oulu, Research unit of logopedics, Child Language Research Center Sari Kunnari, University of Oulu, Research unit of logopedics, Child Language Research Center

This study investigated the performance of four- to eight-year-old (N=171) typically developing children in the Edmonton Narrative Norms Instrument (ENNI). In addition, 19 children with specific language impairment (SLI) and 16 children with autism spectrum disorder (ASD) and their control children participated in order to determine the discriminatory validity of the ENNI. Narratives were analyzed for the amount of information produced (story grammar score, SG) and total number of words (TNW). Results show a developmental trend both in SG and in TNW. In particular, the ENNI seems to differentiate four- and five-year-olds and five- and six-year-olds from each other as well as from older age groups. No differences between girls and boys were detected. Children with SLI and children with ASD showed poorer narrative abilities than their control children. The narratives of children with SLI contained less information and were also shorter than those of typically developing children. For children with ASD, significant differences compared to control children were only seen in SG. Since there are only a few narrative assessment methods available in Finnish, the use of the ENNI might be recommended for analyzing children's narrative skills. However, care should be taken in interpreting the normative values, since high heterogeneity is typical for narration.

Keywords: autism spectrum disorder, narration, specific language impairment, story generation, typical language development 